\title{
Assessment of Ethanol as Fuel Additive to Diesel-Biodiesel Blends on Combustion and Performance Characteristics in CI Engine
}

\author{
K Rajesh, Ganesh D.B
}

\begin{abstract}
Biodiesel is one of the most promising and technically viable partial replacements to the petroleum diesel. Many research works were carried out on diesel -biodiesel blends focusing on the performance and emission aspects of the CI engine. Diesel biodiesel blends encounter with operational problems like higher viscosity, higher surface tension and less intensity atomization of the burning mixing. These set back in the diesel-biodiesel can be overcome by the addition of the ethanol to the diesel -biodiesel mixture. An attempt has been made to use higher concentration of ethanol by using Karanja biodiesel as medium of mixing with diesel. In this paper discussion has been made on the effect on the performance and combustion aspects of CI engine operating on the Diesel-biodiesel-ethanol blends
\end{abstract}

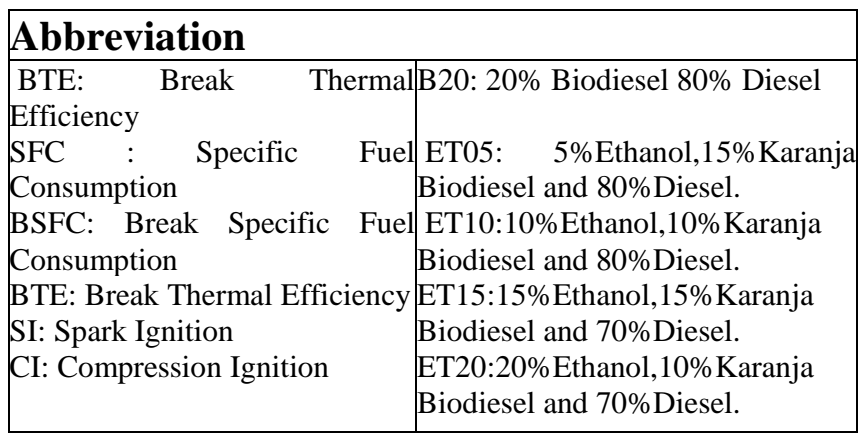

Key words: IC engine; Ethanol; Bio diesel; combustion; performance

\section{INTRODUCTION}

Population development of world is required to help practically 1.5 billion individuals to achieve 8.8 billion by 2035[1]. Due to quicker pace of urbanization when contrasted with the past, by 2040 extra 2 billion might be added to the urban focuses [2]. Consequently prospect of financial development relies upon the long haul avaibility of energy from the sources that are affordable, accessible and however much as could be expected environmental friendly. When contrasted with China, India vitality request development is just about multiple times higher [2]. Constantly 2035, petroleum product (coal, oil, gas) remains the main supporters of worldwide energy needs.

Considering the fuel assets, biodiesel is a most encouraging contrasted with non-renewable energy source. Biodiesel is utmost encouraging elective wellspring of vitality for natural advantages, for example, non-perilous and environmental neighborly [3,4]. Without the

Revised Manuscript Received on July 18, 2019.

K Rajesh (Research Scholar), Dept. of Mechanical Engineering STJ Institute of Technology Ranebennur, India. (E-mail: rajeshkodbal@gmail.com)

Dr Ganesh D.B, Dept. of Mechanical Engineering, G M Institute of Technology, Davangere,India.(E-mail:, ganeshdb36@gmail.com) modification of the engine biodiesel diesel blends can be used with certain amount of the energy loss.

Partial use of biodiesel along with the diesel has some disadvantages like reduced energy content, elevation in the viscosity, tendency of carbon deposition on the fuel line [5]. Energy content of the biodiesel-diesel blend diminishes as the section of the biodiesel rises in the blend because of the inferior content of energy [6]. These shortcomings diminish the combustion and performance aspects of the CI engine [7].

In order overcome the problems related to the biodiesel diesel blend and part replace of both diesel biodiesel, ethanol is added as the third liquid fuel along with the diesel-biodiesel blend. Ethanol is rich source of the oxygen which not only acts as the oxygenating mediator it also cuts the viscosity of the diesel biodiesel blend. Use of ethanol helps the good performance, combustion and emission aspects of the diesel locomotive [8]. Use of ethanol incorporated diesel dates back to 1980 in the diesel locomotive without the modification has been attempted $[9,10]$.

Need for the new energy resources, renewed government policies and use in the petrol brought the ethanol into mainstream in the locomotive fuels research and motives the higher percentage use in the diesel biodiesel blend.

A.C. Hansen et al [11], reviewed the papers on the ethanol-diesel blend, draws the conclusion that ethanol addition to the diesel change the properties with respect to diesel, in particular chemical energy, flowability and the resistance between the two layers of the fluid. Addition of $5 \%$ ethanol by volume reduces $2 \%$ energy content of the diesel fuel. Compared to the diesel operation the diesel ethanol blend use reported with the reduction in the performance in linear proportion reduction in the energy content of the blend. Reduction in the particulate matter were reported in almost all investigations. They attributed this trend to the enrichment of the oxygen content of the blend because of the ethanol.

Dattatray Bapu Hulwan et al [12], investigated the three blends namely blend A (70\% diesel:20\% ethanol:10\% biodiesel), blend B (50\% diesel:30\% ethanol:20\% biodiesel), blend C (50\% diesel:40\% ethanol:10\% biodiesel), compared these blends with the diesel. Conveyed that the trivial rise in the chemical conversion efficiency (BTE), fuel consumption with respect shaft power produced increases, reduction in the smoke opacity at elevated loads

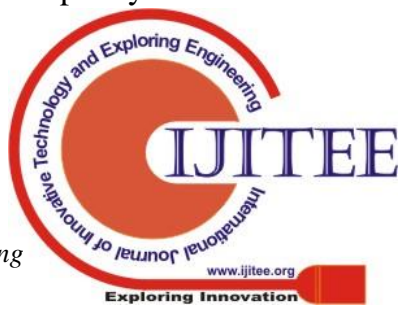




\section{ASSESSMENT OF ETHANOL AS FUEL ADDITIVE TO DIESEL-BIODIESEL BLENDS ON COMBUSTION AND PERFORMANCE CHARACTERISTICS IN CI ENGINE}

noticed. Remarkable decrease in the carbon monoxide tail end emission was noticed at the lower load. Concluded that the blend B showed the substantial performance in terms of performance

S.M. Krishna et al [13], verified the ethanol incorporated diesel biodiesel blend in the diesel engine generator. Six testing blends were investigated starting from the ethanol from $5 \%$ by volume in increment of $1 \%$ by volume up to $10 \%$ ethanol. All the testing blends exhibits the properties in line with the petroleum diesel. The blend which contains the 5\%ethanol-15\%biodies1-78\%diesel tested for the highest heating value with $37.01 \mathrm{MJ}$ which is $4 \%$ less than that of diesel. This blend exhibits lower specific fuel consumption among all blends but $3.7 \%$ higher than that of the diesel. They accredited this to the less energy content of the blend as related to the diesel. Above blend has same conversion efficiency that of the diesel.

F. Pradelle et al [14], experimented with the B15(15\%)biodiesel along with diesel) as base line comparative fuel. Compared this blend with the ethanol proportion from $5 \%$ to $20 \%$ in the B 15 blend. Specific fuel increased by $5 \%$ for $5 \%$ ethanol B 15 blend. Also reported that as ethanol percentage increase the ignition delay also increases owing the lower cetane number. Thermal energy conversion increases with the increase in the ethanol content.

In order to pay a way for the use of higher proportion of ethanol in the diesel-ethanol blends, the karanja biodiesel can be used as a cosolvent and property enhancer. An attempt is made to use higher ratio of ethanol for estimation of the combustion and performance aspects of the CI engine. This paper throws a light on the performance and combustion aspects of the diesel locomotive.

Main motive of the investigation is to use higher content of the ethanol in diesel by using karanja biodiesel as a cosolvent. Illustrative plan of the anticipated work has been denoted in the Fig. 1.

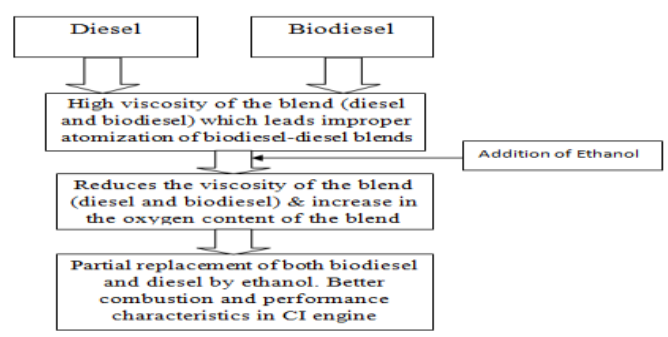

Fig.1 Illustrative plan of the anticipated work

\section{RESOURCES AND APPROACH}

\subsection{Test Engine Setup}

Test were conducted on the single cylinder water cooled diesel engine which is interfaced with the computer to measure the combustion data. Compression ratio of the test engine is 16.5 with displacement $0.11 \mathrm{~m}$ and having the bore $0.08 \mathrm{~m}$. Suitable arrangements were made to measure the speed, fuel consumption. The set illustration is as shown in the Fig. 3 and actual set is as shown in the Fig.2.

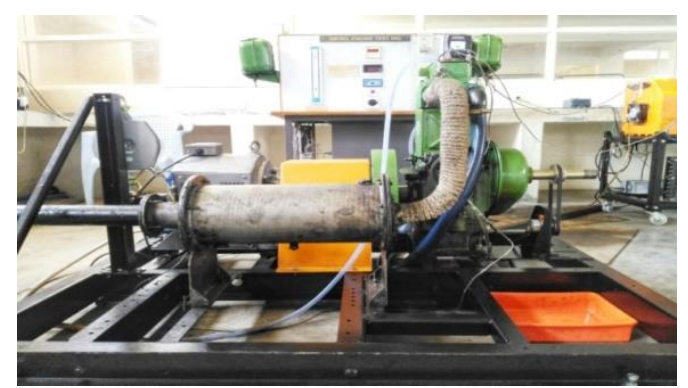

Fig.2 Engine Test Set Up

\subsection{Investigation fuel combinations}

Different fuel combinations were explored

\begin{tabular}{|l|l|l|l|}
\hline Particular & $\begin{array}{l}\text { Density } \\
(\mathrm{Kg} / \mathrm{m} 3)\end{array}$ & $\begin{array}{l}\text { Kinematic } \\
\text { viscosity } \\
\text { (Centistokes })\end{array}$ & $\begin{array}{l}\text { Calorific } \\
\text { Value } \\
(\mathrm{KJ} / \mathrm{kg})\end{array}$ \\
\hline B20 & 808 & 17.026 & 42740 \\
\hline ET05 & 820 & 5.25 & 42340 \\
\hline ET10 & 811 & 4.23 & 41940 \\
\hline ET15 & 809 & 3.52 & 40910 \\
\hline ET20 & 796 & 3.159 & 40510 \\
\hline
\end{tabular}

a) 5\%Ethanol,15\% Karanja Biodiesel and $80 \%$ Diesel. Termed as ET05

b) $10 \%$ Ethanol,10\%Karanja Biodiesel and $80 \%$ Diesel. Termed as ET10

c) $15 \%$ Ethanol,15\%Karanja Biodiesel and 70\%Diesel. Termed as ET15

d) $20 \%$ Ethanol,10\%Karanja Biodiesel and 70\%Diesel. Termed as ET20

All above combinations were prepared by volume basis. Test results from these combinations were compared with the petroleum diesel and B20 blends. Properties of all elements used and combinations of the fuel blends were found and tabulated in table 1 and table 2 respectively.

\subsection{EXPERIMENTAL PROCEDURE}

Engine is started with the diesel, engine is made to run on the diesel for 15 minute. Later it is shifted to the testing combinations. After each test combination engine is again made to run on the diesel for 15 minutes so that the residualfuel is burnt along with the diesel. During the test all the parameter of interest like time taken for $10 \mathrm{ml}$ fuel consumption, cooling water temperature, exhaust gas temperature and eddy current dynameter were tabulated. 


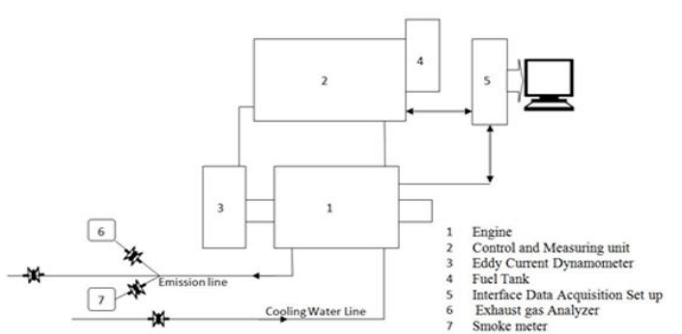

Fig.3 Experimental set up illustration

Table 1 Properties of the three base fuels

Table 2 Properties of the different fuel combinations

\begin{tabular}{|c|c|c|c|}
\hline Particular & $\begin{array}{c}\text { Density } \\
(\mathrm{Kg} / \mathrm{m} 3)\end{array}$ & $\begin{array}{c}\text { Kinematic } \\
\text { viscosity } \\
\text { (Centistoke } \\
\text { s) }\end{array}$ & $\begin{array}{c}\text { Calorific Value } \\
(\mathrm{KJ} / \mathrm{kg})\end{array}$ \\
\hline $\begin{array}{c}\text { Karanja } \\
\text { Biodiesel }\end{array}$ & 840 & 5.14 & 37700 \\
\hline Ethanol & 749 & 2.2 & 29700 \\
\hline Diesel & 850 & 4.2 & 44000 \\
\hline
\end{tabular}

\section{RESULTS AND DISCUSSION}

\begin{tabular}{|l|l|l|l|}
\hline Particular & $\begin{array}{l}\text { Density } \\
(\mathrm{Kg} / \mathrm{m} 3)\end{array}$ & $\begin{array}{l}\text { Kinematic } \\
\text { viscosity } \\
\text { (Centistokes) }\end{array}$ & $\begin{array}{l}\text { Calorific Value } \\
(\mathrm{KJ} / \mathrm{kg})\end{array}$ \\
\hline B20 & 808 & 17.026 & 42740 \\
\hline ET05 & 820 & 5.25 & 42340 \\
\hline ET10 & 811 & 4.23 & 41940 \\
\hline ET15 & 809 & 3.52 & 40910 \\
\hline ET20 & 796 & 3.159 & 40510 \\
\hline
\end{tabular}

\subsection{Performance Test}

\subsubsection{Specific Fuel Consumption}

The results obtained pertaining to the performance of the engine is demonstrated with the help of graphs. Effect of ethanol on specific fuel consumption for blends B20, ET05, ET10, ET15 and ET20 are shown in Fig.4.

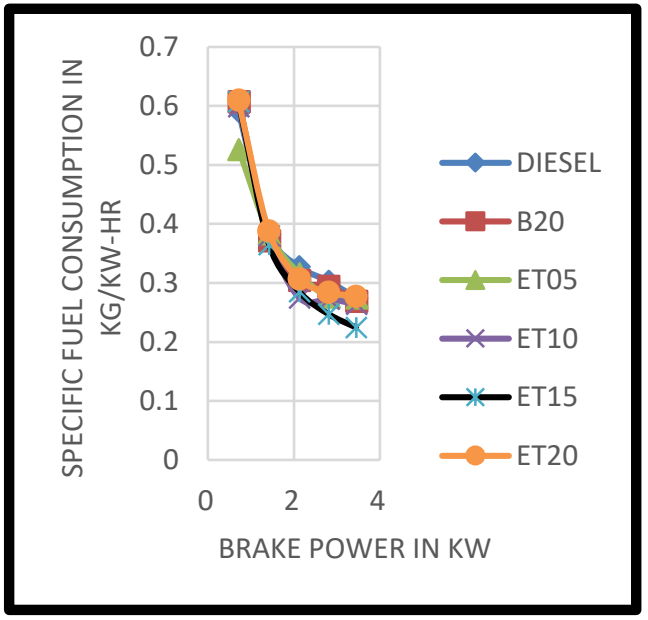

Fig.4 Effect of ethanol on specific fuel consumption

From the above graph, the SFC for B20, ET10, ET15, is agreeing with the pure diesel whereas ET20 shows highest specific fuel consumption and ET05 shows appreciable decrease in specific fuel consumption.
In ET05 percentage of ethanol is 5\% which decreases the viscosity and Oxygen content is increase hence there is a complete combustion which may lead to lower the specific fuel consumption.

For ET20 blend, which shows the highest SFC, reason may be as ethanol percentage increases the chances of pre ignition maybe high since ethanol is the most volatile fuel. Hence the specific fuel consumption is more.

\subsubsection{Energy Conversion (BTE)}

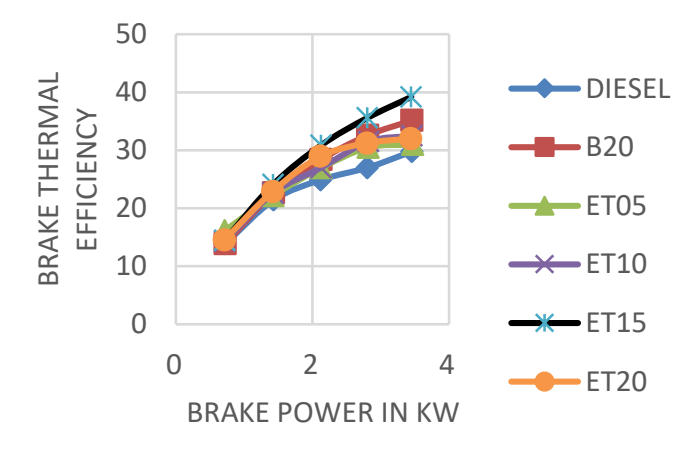

Fig.5 Effect of ethanol on energy conversion (BTE)

Effect of ethanol on energy conversion (BTE) are shown in Fig.5 for different diesel-karanja biodiesel-ethanol blends. From the above graph, for all the blends energy conversion efficiency is higher for ET15 blend and this combination shows the highest energy conversion efficiency.

As ratio of ethanol increases, the energy conversion also rises, by adding ethanol, the viscosity of fuel combination may decreases which in turn promote the good atomization and spray patterns which may lead to complete combustion and hence the heat release rate is high.

\subsection{Combustion Test}

\subsubsection{Heat Release Rate}

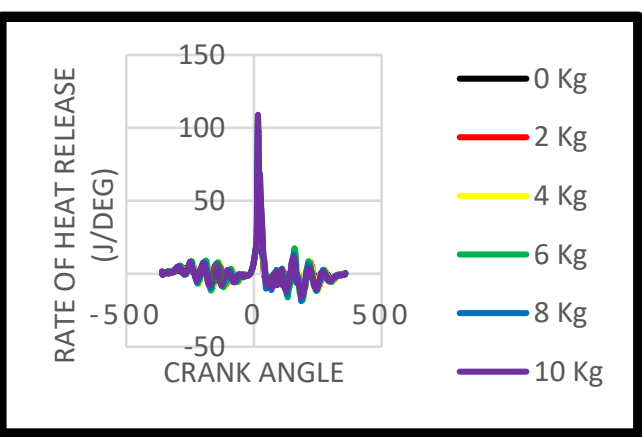

Fig.6 Rate of energy release v/s Crank position for Pure Diesel 


\section{ASSESSMENT OF ETHANOL AS FUEL ADDITIVE TO DIESEL-BIODIESEL BLENDS ON COMBUSTION AND PERFORMANCE CHARACTERISTICS IN CI ENGINE}

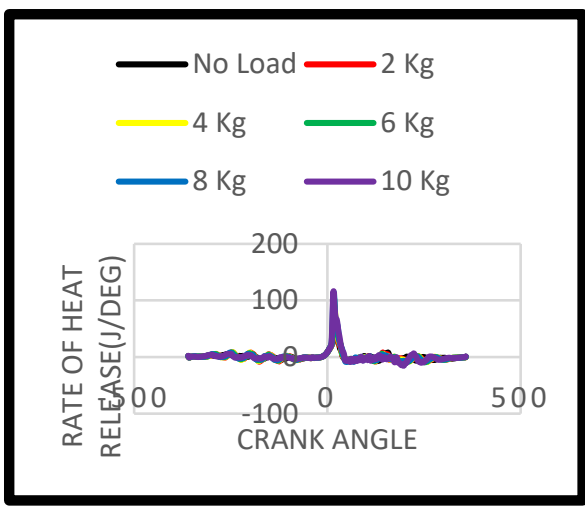

Fig.7 Rate of energy release v/s Crank position for B20

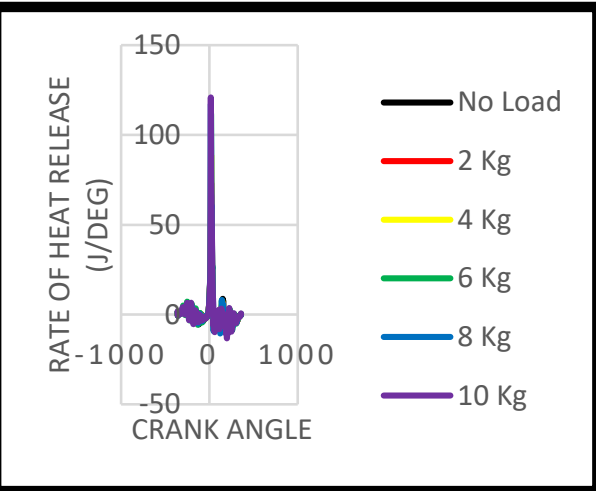

Fig.8 Rate of energy release v/s Crank position for ET05

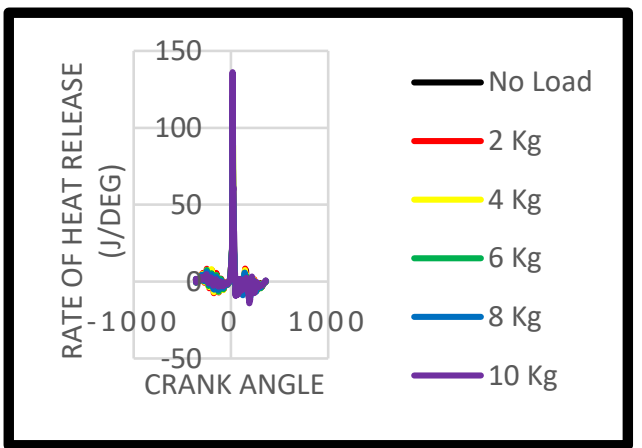

Fig.9 Rate of energy release v/s Crank position for ET10

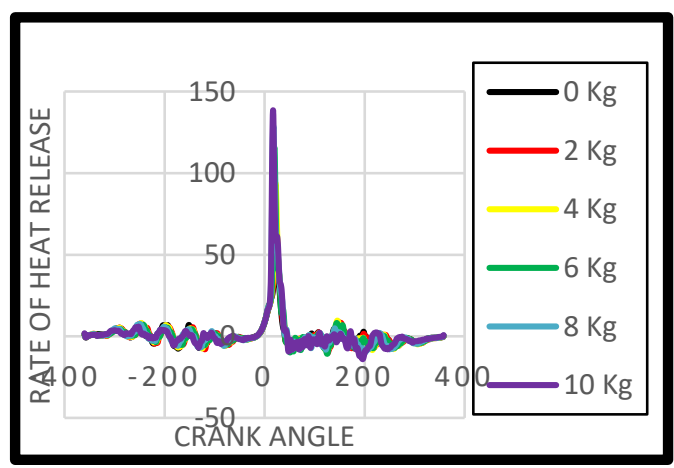

Fig.10 Rate of energy release v/s Crank position for ET15

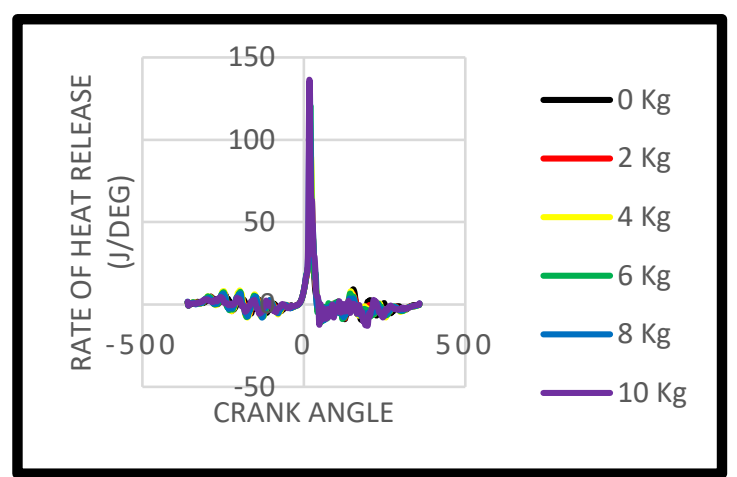

Fig.11 Rate of energy release v/s Crank position for ET20

For different crank angle rate of the energy release for different fuel combination are presented in Fig.6 to Fig.11 for different diesel- karanja biodiesel -ethanol blends. From the above graphs, as load increases, the turbulence may also increase which lead to good air fuel mixture, similarly as load increases, the rate of energy release also increases.

Heat release increases with the increase in percentage of ethanol, this may be because the energy content of the fuel may be increased as there is surge in part of ethanol. As percentage of ethanol increases, oxygen content will increase which may lead to recovering burning, and hence the heat release proportion also increases.

\subsubsection{Peak Pressure}

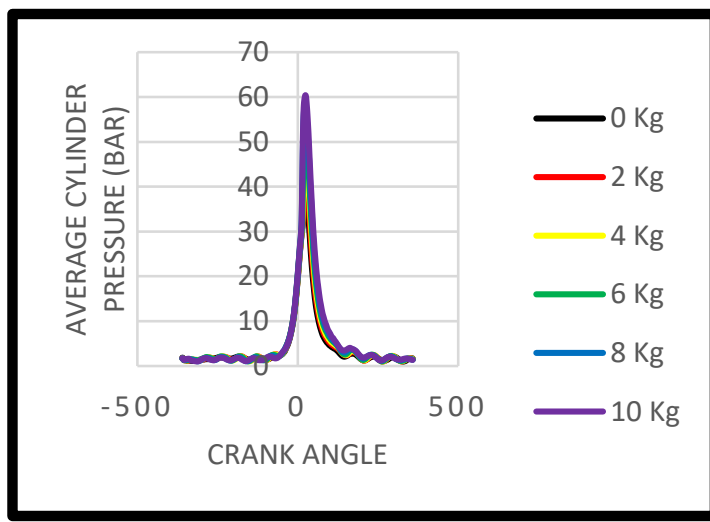

Fig.12 Chamber pressure v/s Crank position for pure diesel

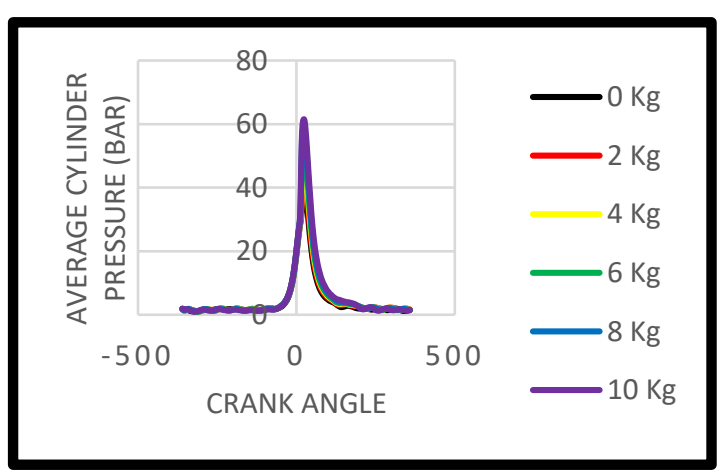

Fig.13 Chamber pressure v/s Crank position for DB20 


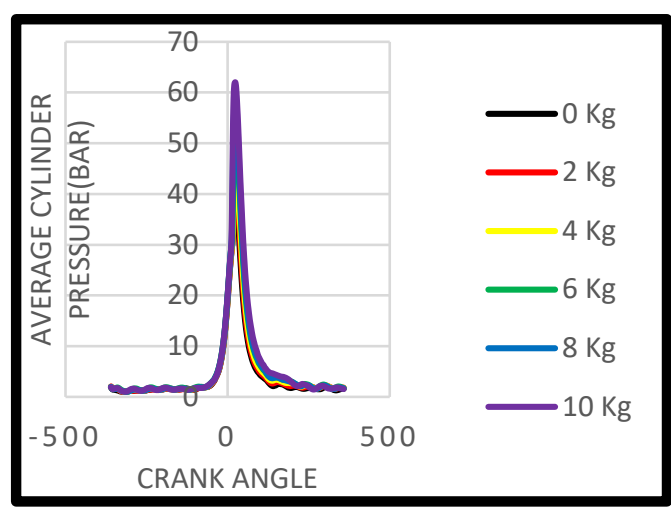

Fig.14 Chamber pressure v/s Crank position for ET05

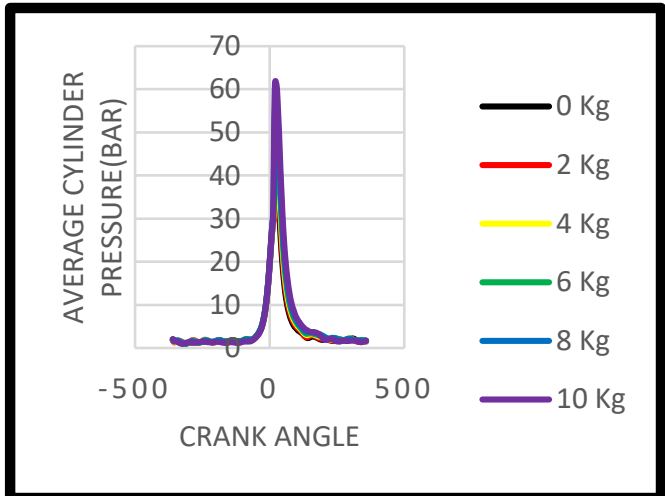

Fig.15 Chamber pressure v/s Crank position for ET10

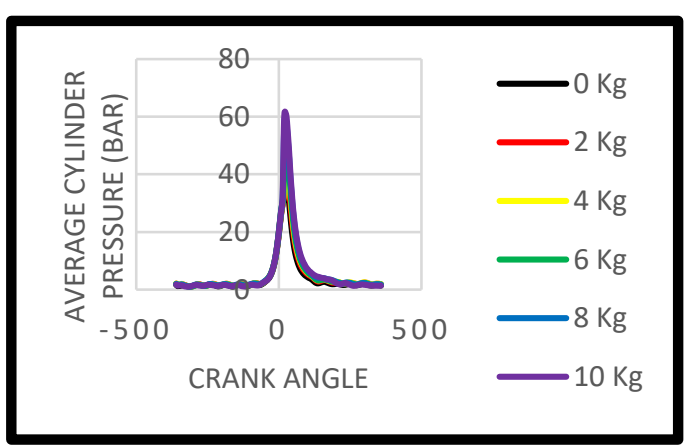

Fig.16 Chamber pressure v/s Crank position for ET15

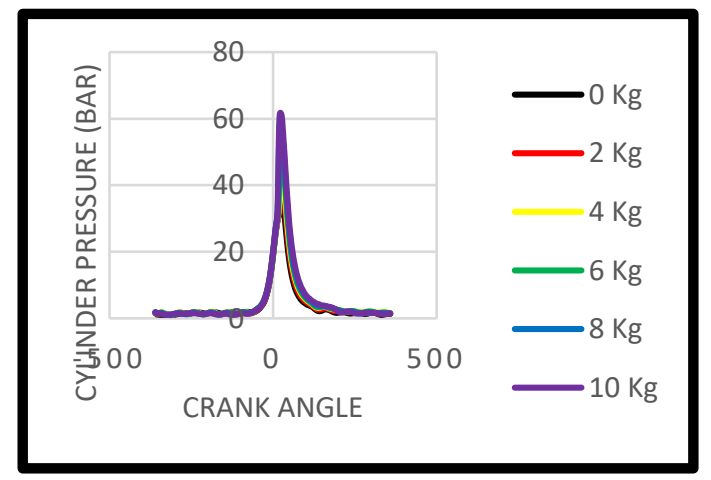

Fig.17 Chamber pressure v/s Crank position for ET20

The cylinder pressure with crank angle for different fuel combination are presented in Fig.12 to Fig.17. from the graphs, it is observed that as load increases, the turbulence may also increases which lead to good air fuel mixture, in the same way as percentage of ethanol increases, oxygen content will increase which may lead to better combustion, and hence the heat release rate also increases.
As percentage of ethanol increases the peak pressure also increases, since the peak pressure is the function of good combustion. As the percentage of ethanol increases, there will be better combustion which in turn increases the peak pressure.

\section{CONCLUSIONS}

Main motive of the paper investigates use higher content of the ethanol in diesel by using karanja biodiesel as a cosolvent.

In ET05 percentage of ethanol is 5\% which decreases the viscosity and Oxygen content is increase hence there is a complete combustion which may lead to lower the specific fuel consumption.

For ET20 blend, which shows the highest SFC, reason may be as ethanol percentage increases the chances of pre ignition may be high since ethanol is the most volatile fuel. Hence the specific fuel consumption is more.

As fraction of ethanol upsurges, the brake thermal efficiency also increases, by adding ethanol, the viscosity of biodiesel may decreases which in turn promote the good atomization and spray patterns which may lead to complete combustion and hence the heat release amount is tall.

As load increases, the turbulence may also increase which lead to good air fuel mixture, similarly as load increases, the degree of heat release also upsurges. Heat release increases with the upsurge in proportion of ethanol, this may be because the energy content of the fuel may be increased as there is increase in percentage of ethanol. As percentage of ethanol increases, oxygen content will increase which may lead to better combustion, and hence the heat release rate also increases.

As percentage of ethanol increases the peak pressure also increases, since the peak pressure is the function of good combustion. As the percentage of ethanol increases, there will be better combustion which in turn increases the peak pressure.

\section{REFERENCES}

1. Statistical Review of World Energy. London: British Petroleum Co, 2017.

2. Statistical Review of World Energy. London: British Petroleum Co, 2018.

3. Janaun, Jidon, and Naoko Ellis. "Perspectives on biodiesel as a sustainable fuel." Renewable and Sustainable Energy Reviews 14.4 (2010): 1312-1320.

4. Shahir, S. A., et al. "Feasibility of diesel-biodieselethanol/bioethanol blend as existing CI engine fuel: An assessment of properties, material compatibility, safety and combustion." Renewable and Sustainable Energy Reviews 32 (2014): 379-395.

5. Prasad, G. and Gupta, A., "Role of Nano Additive Blended Karanja Biodiesel Emulsion Fuel on Performance and Emission Characteristics of Diesel Engine," SAE Technical Paper 2016-28-0165, 2016, doi:10.4271/2016-28-0165.

6. Kumar, Chandan, MK Gajendra Babu, and Lalit M. Das. Experimental Investigations on a Karanja Oil Methyl Ester Fueled DI Diesel Engine. No. 2006-01-0238. SAE Technical Paper, 2006. 
7. Xue, Jinlin, Tony E. Grift, and Alan C. Hansen. "Effect of biodiesel on engine performances and emissions." Renewable and Sustainable energy reviews 15.2 (2011): 1098-1116.

8. Hulwan, DattatrayBapu, and Satishchandra V. Joshi. "Performance, emission and combustion characteristic of a multicylinder DI diesel engine running on diesel-ethanolbiodiesel blends of high ethanol content." Applied Energy88.12 (2011): 5042-5055

9. Hardenberg, H. and Schaefer, A., "The Use of Ethanol as a Fuel for Compression Ignition Engines," SAE Technical Paper 811211, 1981

10. Weidmann, K. and Menrad, H., "Fleet Test, Performance and Emissions of Diesel Engines Using Different Alcohol-Diesel Fuel Blends," SAE Technical Paper 841331, 1984

11. Hansen, Alan C., Qin Zhang, and Peter WL Lyne. "Ethanoldiesel fuel blends - a review." Bioresource technology 96.3 (2005): 277-285.

12. Hulwan, Dattatray Bapu, and Satishchandra V. Joshi. "Performance, emission and combustion characteristic of a multicylinder DI diesel engine running on diesel-ethanolbiodiesel blends of high ethanol content." Applied Energy88.12 (2011): 5042-5055.

13. Krishna, Sachin Muralee, et al. "Performance and emission assessment of optimally blended biodiesel-diesel-ethanol in diesel engine generator." Applied Thermal Engineering 155 (2019): 525-533.

14. Pradelle, Florian, et al. "Performance and combustion characteristics of a compression ignition engine running on diesel-biodiesel-ethanol (DBE) blends-Potential as diesel fuel substitute on an Euro III engine." Renewable energy 136 (2019): 586-598. 